\title{
Dry matter intake and ruminal fermentation parameters in goats fed sugarcane in replacement of corn silage
}

\author{
Parâmetros de ingestão de matéria seca e fermentação ruminal em cabras alimentadas \\ com cana-de-açúcar em substituição à silagem de milho
}

${ }^{1}$ CANIZARES, Gil Ignácio Lara

https://orcid.org/0000-0003-2253-5703

${ }^{2}$ GONÇALVES, Heraldo Cesar

https://orcid.org/0000-0002-5030-5617

${ }^{2}$ MARQUES, Raquel Ornelas

https://orcid.org/0000-0001-9541-7121

${ }^{3}$ LOURENÇON, Raquel Vasconcelos https://orcid.org/0000-0003-2860-7878

${ }^{4 *}$ GOMES, Helen Fernanda Barros

https://orcid.org/0000-0003-1168-0999

${ }^{5}$ BOAVENTURA NETO, Oscar

https://orcid.org/0000-0002-5064-861X

${ }^{1}$ CANIZARES, Marleide Costa

https://orcid.org/0000-0002-9160-9035

${ }^{1}$ Instituto Federal do Rio Grande do Sul - IFRS, Av. Osvaldo Aranha, 540 - Juventude da Enologia, Bento Gonçalves/RS, CEP: 95700-000, Brasil

${ }^{2}$ Faculdade de Medicina Veterinária e Zootecnia - UNESP, Rua Prof. Doutor Walter Mauricio

Correa, s/n - Botucatu/SP - CEP 18618-681,Botucatu-SP

${ }^{3}$ Langston University, PO Box 1500, Langston'OK, EUA

${ }^{4}$ Universidade Federal de Rondonópolis, UFR, Av. dos Estudantes, 5055 - Cidade Universitária, Rondonópolis/MT, CEP: 78736-900, Brasil

${ }^{5}$ Universidade Federal de Alagoas, Av. Lourival Melo Mota, S/N - Tabuleiro do Martins, Maceió/AL, CEP: 57072-900, Brasil

*Mail for correspondence: gomes.helen@ufr.edu.br

\section{ABSTRACT}

The trial was conducted with the objective to evaluate fresh sugarcane as a replacement for corn silage on dry matter intake, ruminal parameters $(\mathrm{pH}$, short chain fatty acids, and ammonia nitrogen concentration), and degradation kinetics of forages and concentrate in maintenance adult goats. Four nonlactating ruminally cannulated goats were used in a 4 $\times 4$ Latin square design with the replacement of $0,33,67$, and $100 \%$ of corn silage by sugarcane as the independent variable. The substitution of sugarcane for corn silage did not affect dry matter intake, daily weight gain, or ruminal $\mathrm{pH}$. A quadratic effect was observed for ammonia nitrogen concentration with a maximum concentration at $74.43 \%$ of sugarcane inclusion, as well as for short chain fatty acids, with maximum concentrations of acetate and butyrate at 0.59 and $32.70 \%$ of sugarcane inclusion, respectively. The minimum concentration of propionate was verified on $10.36 \%$ of sugarcane inclusion. However, the acetate:propionate ratio linearly decreased with increased sugarcane content. No effect was observed of different rumen environments on forage dry matter and neutral detergent fiber degradability (effective and potential 
degradability, soluble and potential degradable fractions). Dry matter degradability was $66.79 \%$ for sugarcane and $72.62 \%$ for corn silage after $96 \mathrm{~h}$ of incubation. Neutral detergent fiber was 37.10 and $51.82 \%$ for sugarcane and corn silage, respectively, after $96 \mathrm{~h}$ of incubation. In conclusion, sugarcane can be used as a replacement for corn silage in maintenance adult goats feed without altering dry matter intake and forage degradability while increasing propionate production.

Keywords: ammonia nitrogen, degradability, dry matter, short chain fatty acids

\section{RESUMO}

O experimento foi conduzido para avaliar a cana-de-açúcar in natura em substituição à silagem de milho no consumo de matéria seca, parâmetros ruminais e cinética de degradação de forragens e concentrado em cabras adultas em mantença. Quatro cabras não lactantes canuladas no rúmen foram utilizadas em um delineamento em quadrado latino $4 \times 4$ com a substituição de $0,33,67$ e $100 \%$ da silagem de milho por cana-deaçúcar. A substituição da cana-de-açúcar pela silagem de milho não afetou o consumo de matéria seca, o ganho de peso diário e o $\mathrm{pH}$ ruminal. Foi observado efeito quadrático para a concentração de nitrogênio amoniacal com concentração máxima de $74,43 \%$ de inclusão da cana, e também para ácidos graxos de cadeia curta, com concentrações máximas de acetato e butirato de 0,59 e $32,70 \%$ de inclusão da cana, respectivamente. A concentração mínima de propionato foi verificada em 10,36\% de inclusão de cana-deaçúcar. No entanto, a relação acetato: propionato diminuiu linearmente com o aumento do teor de cana-de-açúcar. Não foi observado efeito de diferentes ambientes ruminais sobre a degradabilidade da matéria seca da forragem e da fibra em detergente neutro. A degradabilidade da matéria seca foi de $66,79 \%$ para a cana-de-açúcar e $72,62 \%$ para a silagem de milho após $96 \mathrm{~h}$ de incubação. A fibra em detergente neutro foi 37,10 e 51,82\% para cana-de-açúcar e silagem de milho, respectivamente, após 96 h de incubação. Em conclusão, a cana-de-açúcar pode ser usada como substituto da silagem de milho na alimentação de cabras adultas de manutenção, sem alterar o consumo de matéria seca e a degradabilidade da forragem, aumentando a produção de propionato.

Palavras-chave: ácidos graxos de cadeia curta, degradabilidade, matéria seca, nitrogênio amoniacal

\section{INTRODUCTION}

The inclusion of sugarcane in ruminant feed, especially for low production animals, as an available source in a critical period of food scarcity allows for the reduction or replacement of conserved forages, such as silage and hay that have a high costs of production, and are not always accessible for small producers.
Sugarcane can be considered a strategic forage to be used in ruminant feeding because of its high sugar content and forage production per area. However, sugarcane has little nutritive value, limited by its reduced cell wall digestion which contributes to low levels of metabolizable energy for the animal and reduced efficiency of soluble sugars utilization (Carmo et al., 2001). 
Forage feeds consumed by ruminants, such as sugarcane, undergo physical and chemical modifications, generating nutritive compounds, which are products of ruminal fermentation. The rumen is considered a fermentation chamber that presents suitable environmental conditions for the multiplication and development of microorganisms which ferment the feed ingested by the animal, producing necessary nutrients for their survival and short chain fatty acids used by the host as an energy source for different metabolic processes. Therefore, the nature of the diet, dry matter intake level, and rumination are determinant factors in ruminal fermentation (Carvalho et al., 2003).

The present trial was designed with the objective to evaluate the effects of replacing $0,33,67$, and $100 \%$ of corn silage with fresh sugarcane on dry matter intake, ruminal fermentation parameters, and in situ rumen degradability in maintenance adult goats.

\section{MATERIALS AND METHODS}

Four nonpregnant and nonlactating ruminally cannulated goats with live weight of $42.45 \pm 4.40 \mathrm{~kg}$ were used in this experiment, according to the guidelines established by São Paulo State University (Brazil) Ethical Committee for Animal Research. The goats were housed in a covered shelter, placed in individual pens of $3.5 \mathrm{~m}^{2}$ with free access to drinkers, salt, and feed bunks. Experimental diets were offered twice daily, at 08:00 and 16:00, as total mixed rations, in a quantity to allow $10 \%$ surplus of feed. Water was supplied ad libitum.
The experimental design was a $4 \times 4$ Latin square used to evaluate the effect of four diets structured by the replacement by fresh chopped sugarcane for corn silage, on a dry matter basis, in proportions of $0,33,67$, and $100 \%$ as follows: Treatment $0(0 \%$ sugarcane, $100 \%$ corn silage); Treatment 33 (33\% sugarcane, $67 \%$ corn silage); Treatment 67 (67\% sugarcane, 33\% corn silage); and Treatment 100 (100\% sugarcane, $0 \%$ corn silage).

Sugarcane was chopped daily and combined with the concentrate along with corn silage, according to a forage: concentrate ratio of 40:60, on dry matter basis. Experimental diets were formulated to be isoproteic and the ingredients used were evaluated according to methodology described by AOAC (1997) (Table 1). Neutral detergent fiber (NDF) and acid detergent fiber (ADF) were determined according to methodology described by Van Soest et al. (1991). Nonfiber carbohydrates (NFC) and total digestible nutrients (TDN) were estimated according the equations: $\mathrm{NFC}=100-(\% \mathrm{CP}+\% \mathrm{EE}+$ $\% \mathrm{ASH}+\% \mathrm{NDF})$, Van Soest et al. (1991); and TDN = DCP + DNFC + $\mathrm{DNDF}+(\mathrm{DFA} \times 2.25)-7,(\mathrm{NRC}, 2001)$, where DCP represents protein digestibility, DNFC is nonfiber carbohydrate digestibility, DNDF denotes neutral digestible fiber digestibility, and DFA represents fatty acids digestibility. Metabolizable energy (ME) was determined using TDN and digestible energy (DE) values, suggested by NRC (2001), where: DE (Mcal $/ \mathrm{kg})=$ $0.04409 \times \mathrm{TDN}(\%)$ and $\mathrm{ME}(\mathrm{Mcal} / \mathrm{kg})$ $=1.01 \times \mathrm{DE}(\mathrm{Mcal} / \mathrm{kg})-0.45$.

Table 1. Ingredient and chemical composition of the experimental diets 


\begin{tabular}{|c|c|c|c|c|}
\hline & \multicolumn{4}{|c|}{ Replacement levels (\%) } \\
\hline & 0 & 33 & 67 & 100 \\
\hline \multicolumn{5}{|l|}{ Ingredient, \% DM } \\
\hline Sugarcane & - & 13.2 & 26.8 & 40.0 \\
\hline Corn silage & 40.0 & 26.8 & 13.2 & - \\
\hline Dry-ground corn & 42.6 & 41.5 & 40.2 & 39.0 \\
\hline Soybean meal & 13.8 & 14.8 & 16.0 & 17.1 \\
\hline Limestone & 1.00 & 1.00 & 1.00 & 1.00 \\
\hline Dicalcium phosphate & 1.00 & 1.00 & 1.00 & 1.00 \\
\hline Urea & 0.60 & 0.70 & 0.80 & 0.90 \\
\hline Mineral premix & 1.00 & 1.00 & 1.00 & 1.00 \\
\hline \multicolumn{5}{|l|}{ Composition (\% DM) } \\
\hline Dry matter & 67.2 & 66.4 & 65.7 & 64.9 \\
\hline Organic matter & 96.2 & 96.5 & 96.8 & 97.1 \\
\hline Ash & 3.80 & 3.50 & 3.20 & 2.90 \\
\hline Crude protein & 15.2 & 15.1 & 15.1 & 15.1 \\
\hline Ether extract & 4.10 & 3.80 & 3.40 & 3.10 \\
\hline Neutral detergent fiber & 20.0 & 21.1 & 22.3 & 23.4 \\
\hline Acid detergent fiber & 12.4 & 12.8 & 13.2 & 13.6 \\
\hline Nonfiber carbohydrate & 55.0 & 54.8 & 54.4 & 54.1 \\
\hline Calcium & 0.80 & 0.80 & 0.80 & 0.80 \\
\hline Phosphate & 0.50 & 0.40 & 0.40 & 0.40 \\
\hline Total digestible nutrients & 83.2 & 80.8 & 78.1 & 74.3 \\
\hline Metabolizable energy (Mcal/kg of DM) & 3.325 & 3.215 & 3.092 & 2.918 \\
\hline
\end{tabular}

The experimental period was $92 \mathrm{~d}$, divided into four periods of $23 \mathrm{~d}$, with the first $12 \mathrm{~d}$ used for diet adaptation and adjustment of dry matter intake, and the final $11 \mathrm{~d}$ for sample collection. Five days of each period were used for recording dry matter feed intake, one day for rumen fluid collection for determining rumen $\mathrm{pH}$, short chain fatty acids (SCFA), and ammonia nitrogen
$\left(\mathrm{NH}_{3}-\mathrm{N}\right)$ concentration, and five days for DM and NDF in situ degradability of forages.

To establish the rumen fermentation parameters, rumen fluid samples were collected every $2 \mathrm{~h}$ for $12 \mathrm{~h}$, starting at 08:00, before the offering of experimental diets, and finishing at 20:00, for a total of seven samplings. Approximately $200 \mathrm{~mL}$ of rumen content 
was collected from different parts of the rumen and filtered through multiple layers of cheesecloth to separate the liquid from the solid. After sampling collection, both parts were returned to the rumen. At the sampling day, diets were delivered to animals at 08:00 and 20:00.

Immediately after collection, $100 \mathrm{~mL}$ of rumen fluid was used for $\mathrm{pH}$ determination using a portable digital $\mathrm{pH}$ meter (HANNA instruments Limited HI8424, Bedfordshire, UK) calibrated with solutions of $\mathrm{pH} 4.0$ and 7.0.

For SCFA and $\mathrm{NH}_{3}-\mathrm{N}$ determination, samples of rumen fluid were placed in 15 $\mathrm{mL}$ tubes and centrifuged at $3,000 \times \mathrm{g}$ for $15 \mathrm{~min}$ at room temperature. From the supernatant, $2 \mathrm{~mL}$ were transferred to vacutainer tubes containing $0.4 \mathrm{~mL}$ of formic acid for SCFA determination and $1 \mathrm{~mL}$ of $\mathrm{H}_{2} \mathrm{SO}_{4}$ for $\mathrm{NH}_{3}-\mathrm{N}$ determination. These samples, in duplicate, were stored at $-20{ }^{\circ} \mathrm{C}$ for further analysis. Acetate, propionate, and butyrate determination were measured by gas chromatography (Finnigan 9001 , USA) using a glass column of $1.22 \mathrm{~m}$ in length and $0.63 \mathrm{~cm}$ in diameter packed with 80/120 Carbopack B-DA/4\% (Supelco, Sigma-Aldrich, St. Louis, MO, USA). Ammonia nitrogen concentration determination was done by colorimetric technique, according to Kulasek (1972) and adapted by Foldager (1977).

Degradability of sugarcane NDF and corn silage starch was accomplished using the in situ technique described by Mehrez and Ørskov (1977). Nylon bags with a porosity of $50 \mu \mathrm{m}(10.0 \times 20.0$ $\mathrm{cm})$ were filled with approximately $4 \mathrm{~g}$ of feed previously dried at $55^{\circ} \mathrm{C}$ for $72 \mathrm{~h}$ with an incubation area of $10 \times 10 \mathrm{~cm}$, according to Vanzant et al. (1998). Bags were weighed, tied, and stored in a refrigerator $\left(5{ }^{\circ} \mathrm{C}\right)$ before use. Nylon bags were attached to the rumen cannula by a nylon thread with a minimum of 50 cm length and incubated during $0,6,12$, $24,48,72$, and $96 \mathrm{~h}$ in each experimental period. After incubation, all bags were washed thoroughly by hand and dried at $55^{\circ} \mathrm{C}$ for $72 \mathrm{~h}$ for further weighing and chemical analyses. Degradability at time zero was measured by washing bags in water $\left(39^{\circ} \mathrm{C}\right)$ for $15 \mathrm{~min}$.

For dry matter degradability the following formula was used: $\mathrm{DMDg} \%=$ $100 \times[1$ - $($ BWAI - EBW)/(BWBI $\mathrm{EBW})]$, where $\mathrm{DMDg} \%=\mathrm{DM}$ degradability in percentage, BWAI = bag weight after incubation, $\mathrm{BWBI}=$ bag weight before incubation, and EBW = empty bag weight. The model proposed by Ørskov and McDonald (1979) was used to estimate degradation parameters: $p=a+b\left(1-e^{-c t}\right)$, where " $p$ " is the degradation at each period, "a" is the soluble fraction, " $b$ " is the potentially degradable fraction of the insoluble fraction that would be degraded at a rate "c", and "c", is the rate of degradation of fraction " $b$ ", and " $t$ " is the incubation period in hours.

The parameters $a, b$, and $c$ of the exponential equation generated by PROC NLIN of SAS (2008) were used to calculate the potential degradability $(\mathrm{Pd}=\mathrm{a}+\mathrm{b})$, which represented the quantity of feed that could be solubilized or degraded in the rumen if time was not a limiting factor. The effective ruminal degradability (Ed) which represented the quantity of feed actually degraded in the rumen was calculated according the mathematic model proposed by Ørskov and McDonald (1979): $\mathrm{Ed}=\mathrm{a}+[(\mathrm{b} \times$ $\mathrm{c}) /(\mathrm{c}+\mathrm{k})]$, where $\mathrm{k}$ is the ruminal passage rate of solids, defined as 0.02 and $0.05 \% / \mathrm{h}$. When parameter "a" was 
negative, data were adjusted in an alternative model: $p=b\left(1-e^{-c(t-L)}\right)$, where $\mathrm{L}$ represents the colonization time (McDonald, 1981) and the estimation of Ed and Pd were calculated as described above, only considering the parameter "a" as zero.

Data were subjected to variance analysis (ANOVA) by PROC MIXED of SAS (2008) using the effects of treatment, period, and animal. The variables ruminal $\mathrm{pH}$ and total rumen concentration of SCFA and NH3-N were added to the model above with consideration of the effect of repeated measures in time, based on the different sampling intervals. The parameters revealing significant effects for treatment and/or time were evaluated by polynomial regression. In all analyses, the significance level adopted was $5 \%$ of probability.

\section{RESULTS AND DISCUSSION}

Ammonia nitrogen $\left(\mathrm{NH}_{3}-\mathrm{N}\right)$ concentration was influenced by the substitution levels of corn silage by sugarcane $(P<0.05)$. However, dry matter intake and ruminal $\mathrm{pH}$ were not affected by the treatments (Table 2 ).

Table 2. Dry matter intake (DMI), ruminal $\mathrm{pH}$, and ammonia nitrogen $\left(\mathrm{NH}_{3}-\mathrm{N}\right)$ concentration as functions of sugarcane levels in diets

\begin{tabular}{|c|c|c|c|c|c|c|c|c|}
\hline \multirow{2}{*}{ Variable } & \multicolumn{4}{|c|}{ Replacement levels (\%) } & \multirow{2}{*}{ Mean } & \multirow{2}{*}{$\begin{array}{l}\text { CV } \\
(\%)\end{array}$} & \multicolumn{2}{|c|}{ Regression } \\
\hline & 0 & 33 & 67 & 100 & & & $\mathrm{~L}$ & Q \\
\hline DMI (kg/d) & 1.60 & 1.53 & 1.56 & 1.48 & 1.54 & 8.21 & ns & ns \\
\hline Ruminal pH & 6.14 & 6.15 & 6.08 & 6.15 & 6.13 & 6.43 & ns & ns \\
\hline $\mathrm{NH}_{3}-\mathrm{N}(\mathrm{mg} / \mathrm{dL})$ & 21.1 & 23.6 & 28.1 & 25.0 & 24.2 & 30.79 & ns & $*$ \\
\hline
\end{tabular}

$\overline{\mathrm{CV}}=$ coefficient of variation; $\mathrm{ns}=$ non-significant; $*=\mathrm{P}<0.05 ; \mathrm{L}=$ linear effect; $\mathrm{Q}=$ quadratic effect.

Mean dry matter intake $(1.54 \mathrm{~kg} / \mathrm{d})$ was superior to the requirements for maintenance adult goats with live weight of $40 \mathrm{~kg}$ (NRC, 2007). The greater dry matter intake can be related to the higher level of concentrate $(60 \%)$ in diets, which increases the energy density. As dry matter intake is regulated by energy demand (Mertens, 1996), the increase in concentrate proportion in ruminant diets resulted in higher dry matter intake, allowing for an increase in digestible organic matter and decrease in fiber concentration, avoiding the effect of rumen repletion. This higher dry matter intake can explain the daily weight gain of goats during the experiment $(55 \mathrm{~g} / \mathrm{d})$.
Mean ruminal $\mathrm{pH}$ was 6.13 which was lower than the 6.30 and 6.74 values found by Valvasori et al. (2001) and Magalhães et al. (2006), respectively, in diets with sugarcane and/or corn silage inclusion for cattle. The higher concentrate level could have contributed to ruminal $\mathrm{pH}$ reduction to values that could have affected structural carbohydrate fermenting microorganisms. According to Hoover (1986), a ruminal $\mathrm{pH}$ decrease to approximately 6.0 causes less reduction in fiber digestion. Gonçalves et al. (2001) observed a ruminal $\mathrm{pH}$ reduction from 7.05 to 5.85 in diets with 0 and $80 \%$ of concentrate for dairy goats, 
respectively. According to those authors, ruminal $\mathrm{pH}$ drop was related to lower rumination activity which reduced saliva production with consequent buffering reduction.

Ruminal $\mathrm{pH}$ drop was observed approximately $2 \mathrm{~h}$ after the first feeding (08:00), and can be consequence of a higher proportion of concentrate in the diets or selectivity by the animals, choosing first the concentrate and juicy parts of forage, although diets were supplied as total mixed rations (Figure 1). The decreased rumen $\mathrm{pH}$ was within that of Ørskov (1986), at 0.5 to $4 \mathrm{~h}$ after feeding, characterizing the peak of fermentation, at which time the $\mathrm{pH}$ drop can result in a nutritional disturbance such as acidosis, a result of excessive acid accumulation in the rumen. Ruminal $\mathrm{pH}$ values were below 6.2 at the majority

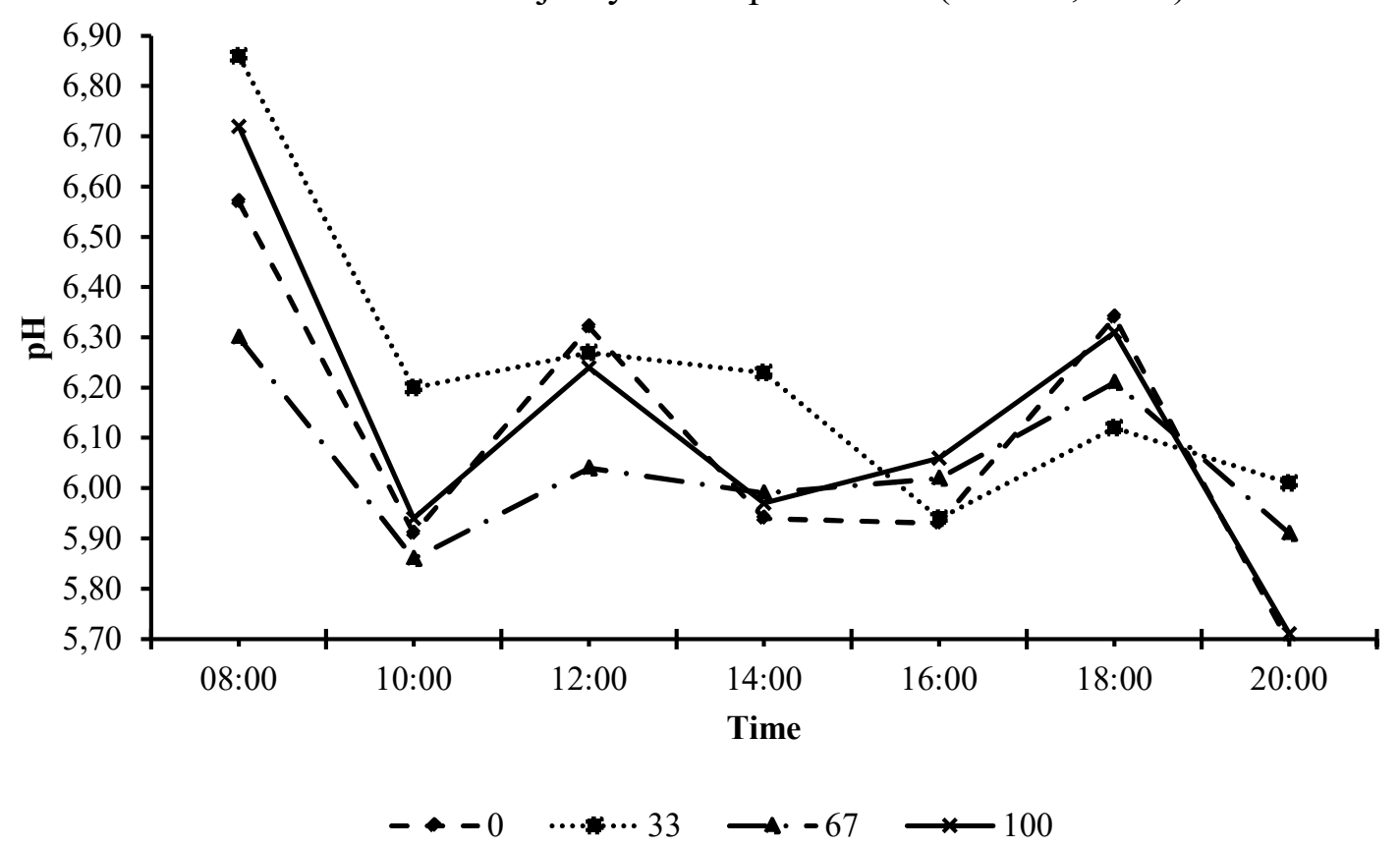

of sampling times, which can inhibit structural carbohydrate fermenting microorganisms and significantly reduce microbial protein synthesis (Strobel \& Russell, 1986). Under normal conditions, structural carbohydrate fermenting microorganisms grow well in ruminal pH near 6.7 (Hoover \& Stokes, 1991; Valadares et al., 2006). Ruminal $\mathrm{pH}$ peaks were observed at approximately 12:00 and 18:00, which can be attributed to the goat feeding time and rumination. Ruminal $\mathrm{pH}$ is a variable correlated to ingestive behavior of the animal and is dependent on mastication and salivation times, as well as the frequency of ingestion and rumination, which could be maintained in normal conditions by the increase of saliva neutralization power or reduced by acid production (Church, 1993).

Figure 1. Effect of substitution of corn silage by sugarcane on ruminal $\mathrm{pH}$ as a function of time

The mean value of ammonia nitrogen ruminal concentration was 24.20 $(\mathrm{mg} / \mathrm{dL})$ and a quadratic effect was observed at the maximum concentration of $26.32(\mathrm{mg} / \mathrm{dL})$ for the level $74.43 \%$ of sugarcane inclusion in diet. These values were higher than those found by Valvasori et al. (2001) and Magalhães et 
al. (2006), of 18.82 and $11.32 \mathrm{mg} / \mathrm{dL}$, respectively.

The highest level of urea inclusion with sugarcane diets could have contributed to the increase of $\mathrm{NH}_{3}-\mathrm{N}$ to the level of $74.43 \%$ of sugarcane replacement and the decrease of this concentration to the participation of soluble carbohydrates in $100 \%$ of sugarcane, favoring bacteria in ammonia for microbial protein production.

$\mathrm{NH}_{3}-\mathrm{N}$ concentration peak generally occurred $2 \mathrm{~h}$ after feeding (Figure 2), which can be attributed to the excess of crude protein in maintenance goat diets and the urea present in the concentrate. According to Santos (2006), in diets containing urea, ammonia nitrogen peak normally occurs $1-2 \mathrm{~h}$ after feeding and in the case of true protein, at 3-5 $\mathrm{h}$ after feeding, depending on ruminal degradability of this source. After the peak of concentration, $\mathrm{NH}_{3}-\mathrm{N}$ decreased along sampling time. This fact indicates that part of this production was used by rumen microorganisms to synthesize microbial protein, which is recycled in the rumen and the excess eliminated in the urine.

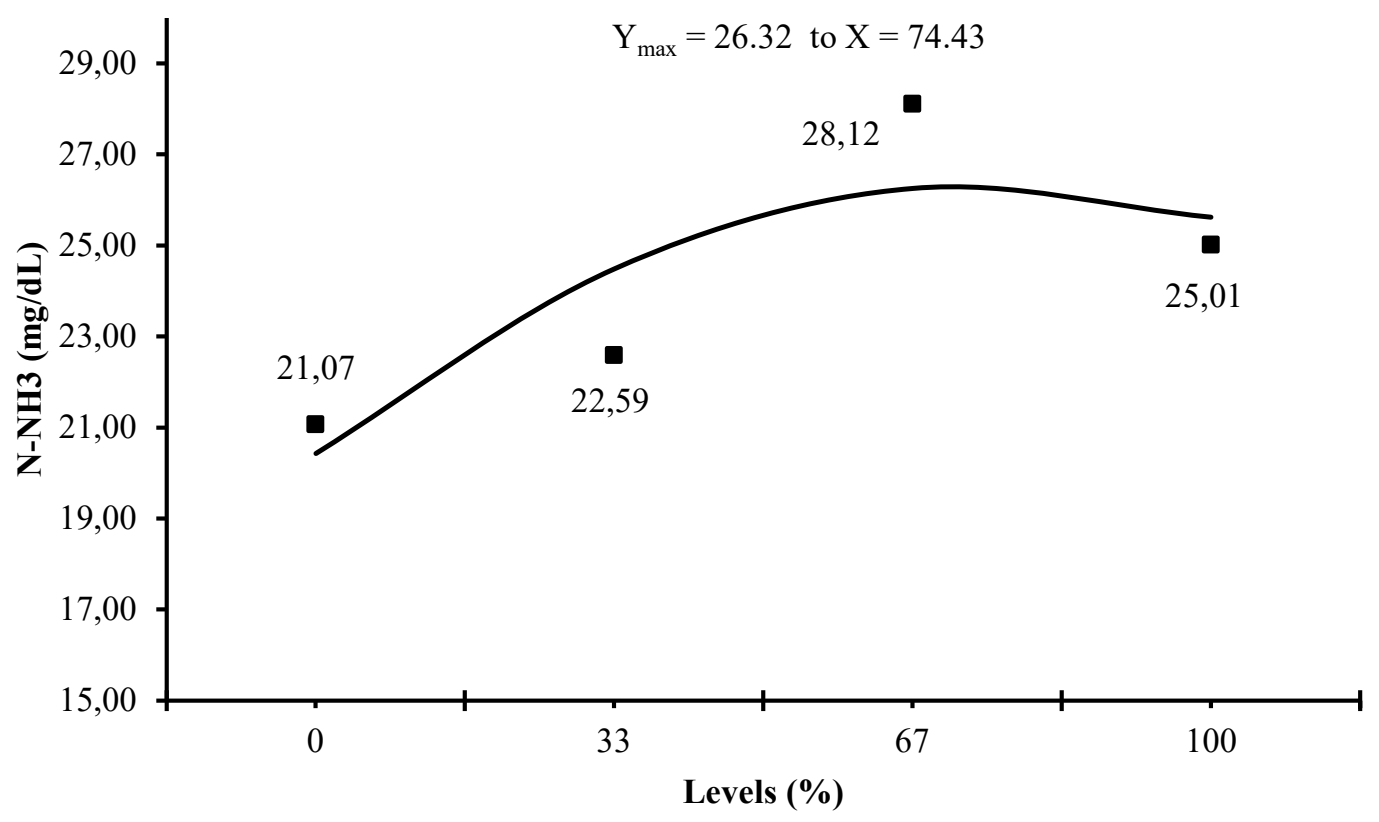

Figure 2. Ammonia nitrogen concentration as related to levels of substitution of corn silage by sugarcane

Significant differences $(P<0.05)$ were observed for short chain fatty acid (SCFA) concentration, molar proportions of acetate, propionate, and butyrate, and acetate:propionate ratio in the levels of corn silage replacement by sugarcane as a function of sampling time (Table 3). However, there was no interaction between treatment and time. 
Table 3. Concentrations of total short chain fatty acids (SCFA), molar proportions of acetate, propionate, and butyrate, and acetate:propionate (Ac:Pr) ratio as a function of levels of sugarcane inclusion in diets and sampling time.

\begin{tabular}{|c|c|c|c|c|c|c|c|c|}
\hline \multirow{2}{*}{ Variable } & \multicolumn{4}{|c|}{ Replacement levels (\%) } & \multirow{2}{*}{ Mean } & \multirow{2}{*}{$\begin{array}{l}\text { CV } \\
(\%)\end{array}$} & \multicolumn{2}{|c|}{ Regression } \\
\hline & 0 & 33 & 67 & 100 & & & $\mathrm{~L}$ & Q \\
\hline Acetate (mol/mol) & 63.31 & 61.56 & 61.49 & 57.24 & 60.90 & 4.32 & ns & $*$ \\
\hline Acetate - time & & & & & & & ns & $*$ \\
\hline Propionate $(\mathrm{mol} / \mathrm{mol})$ & 22.10 & 24.19 & 23.50 & 30.35 & 25.04 & 16.21 & ns & $*$ \\
\hline Propionate - time & & & & & & & ns & $*$ \\
\hline Butyrate (mol/mol) & 14.59 & 14.25 & 15.00 & 12.41 & 14.06 & 15.42 & ns & $*$ \\
\hline Butyrate - time & & & & & & & ns & $*$ \\
\hline Total SCFA (mM) & 89.62 & 87.70 & 79.09 & 89.66 & 86.52 & 17.41 & ns & $*$ \\
\hline Total SCFA - time & & & & & & & $*$ & ns \\
\hline Ac:Pr ratio & 2.96 & 2.40 & 2.73 & 2.11 & 2.61 & 21.52 & $*$ & ns \\
\hline Ac:Pr ratio - time & & & & & & & ns & $*$ \\
\hline
\end{tabular}

$\mathrm{CV}=$ coefficient of variation; $\mathrm{ns}=$ non-significant; $*=\mathrm{P}<0.05 ; \mathrm{L}=$ linear effect; $\mathrm{Q}=$ quadratic effect.

Acetate and butyrate molar proportions had quadratic effects, where the maximum concentration was recorded at 0.59 and $32.70 \%$ of corn silage substitution by sugarcane, respectively. In contrast, propionate showed a minimum concentration at $10.36 \%$ of sugarcane (Table 3 ). These results were contrary to those found by Valvasori et al. (2001) in maintenance cows fed $60 \%$ forage diets containing corn silage replacement levels by sugarcane. Soluble carbohydrates presented in sugarcane can contribute to the energy supply for rumen microorganisms, and consequently to short chain fatty acid production, especially propionate. According to Sutoh et al. (1996), sucrose in the diet increased crude energy in the rumen and could intensify organic matter digestibility of ingested feed. The rumen fermentation products are determined by the nature of the diet that can change the metabolic activity of microorganisms
(Bergman, 1990), such as the drop of rumen $\mathrm{pH}$ to values that favor the growth of nonfiber carbohydrate fermenting microorganisms. Consequently, the acetate:propionate ratio decreased. The frequency in which nutrients flow to rumen also affects different peaks of acetate and propionate molar proportions.

For short chain fatty acid concentrations a quadratic effect was observed $(P<0.05)$, in contrast to Valvasori et al. (2001) in diets with $60 \%$ of forage inclusion, who returned no difference in SCFA concentration when corn silage was replaced by sugarcane. Possibly, the preference of goats for concentrate and corn silage as opposed to sugarcane influenced the higher productions of SCFA in diets with 0 and $100 \%$ replacement. The mean of acetate, propionate, and butyrate molar proportions was 61:25:14, respectively. These values are similar to those found 
by Valvasori et al. (2001), of acetate, propionate, and butyrate rates, 62:25:13, while for diets with a forage:concentrate ratio of $60: 40$, proportions of $60: 26: 14$ were obtained, which are values presenting patterns of fermentation expected for the forage:concentrate ratio of 30:70. According to Bergman (1990), molar proportions of acetate, propionate, and butyrate can vary from $75: 15: 10$ to 40:40:20. The acetate:propionate ratio decreased with increased substitution levels of corn silage by sugarcane, which is related to the higher production of propionate in relation to acetate with the increase in soluble carbohydrates of sugarcane.

Sampling time had a quadratic effect $(P<0.05)$ on the molar proportions of acetate, propionate, and butyrate, with higher propionate and lower acetate and butyrate proportions. These values are reflected in the total concentration of SCFA and the acetate:propionate ratio. The participation of concentrate in diet $(60 \%)$ and dry matter intake of goats, given preference for the concentrate, could favor the acetate molar proportion over propionate and alter their relationship along sampling time. Concentrate diets favored rumen $\mathrm{pH}$ drop, and therefore fermentative activity in the rumen, especially of starch fermenting bacteria with total SCFA production, particularly propionate. According to Valadares et al. (2006), in high concentrate diets, ruminal $\mathrm{pH}$ selects sensible microorganisms and when it declines below 6.2, nonfiber carbohydrate fermenting bacteria which are resistant to acidity increase, whereas structural carbohydrate bacteria decrease. Therefore, amylase activity relative to cellulase increases.
Potential degradability (Pd), soluble fraction (A), potentially soluble fraction (B), degradation rate (C), and effective degradability (Ed) for 0.02 and $0.05 / \mathrm{h}$ of forage DM were not affected $(P>0.05)$ by the different rumen environments from diets with corn silage substitution by sugarcane (Table 4 ). Possibly because of the higher participation of concentrate in diets and a particle size similar to forage, the ruminal environments did not differ. According to Valadares et al. (2006), the decrease of fibrous carbohydrate fermenting microorganisms in animals fed high concentrate diets is related to fiber particle size and passage rate.

Potential degradability of sugarcane dry matter was $65.80 \%$. This value was higher than those observed by Pinto et al. (2007) of 54.73 and $62.01 \%$ for sugarcane treated with 0 and $3 \%$ of sodium hydroxide, respectively, and lower than what was found by Aroeira et al. (1995) of $77.50 \%$, in cattle fed sugarcane supplemented with cotton meal in the ratio 77.5:22.5. Santos et al. (2008) observed a difference in Pd of sugarcane dry matter in cattle fed fresh and ensiled sugarcane (means of 51.27 and $62.68 \%$, respectively).

Degradability values of fractions A $(41.38 \%)$ and B $(24.42 \%)$ of sugarcane dry matter were higher than what was observed by Pinto et al. (2007), of $37.41 \%$ and $17.79 \%$, respectively. The higher degradability of fraction A of sugarcane can be attributed to its soluble sugar content. According to Franzolin and Franzolin (2000), the higher level of soluble sugar (sucrose) in sugarcane cellular content is readily available for microbial fermentation. Those authors, in studies of sugarcane degradability, observed values for fraction A of 48.00 
and $47.00 \%$ and for fraction $\mathrm{B}$ of 33.00 and $31.00 \%$ in buffalo and cattle, respectively.

Table 4. Values of soluble fraction (A) and potentially soluble fraction (B) degradability, degradation rate $(\mathrm{C})$, and effective degradability $(\mathrm{Ed})$ for passage rates of 2.00 and $5.00 \%$ per hour and potential degradability $(\mathrm{Pd})$ of forage dry matter as a function of sugarcane levels in replacement of corn silage

\begin{tabular}{lllllllll}
\hline \multirow{2}{*}{ Variable } & \multicolumn{3}{c}{ Replacement levels (\%) } & \multirow{2}{*}{ Mean } & CV $(\%)$ & \multicolumn{3}{c}{ Regression } \\
\cline { 2 - 3 } & 0 & 33 & 67 & 100 & & & L \\
\hline
\end{tabular}

Dry matter degradability of sugarcane (\%)

\begin{tabular}{lcccccccc}
$\mathrm{A}$ & 41.71 & 41.58 & 41.42 & 40.81 & 41.38 & 1.98 & $\mathrm{~ns}$ & $\mathrm{~ns}$ \\
$\mathrm{~B}$ & 23.89 & 24.80 & 24.50 & 24.50 & 24.42 & 5.97 & $\mathrm{~ns}$ & $\mathrm{~ns}$ \\
$\mathrm{C}(\% / \mathrm{h})$ & 0.04 & 0.05 & 0.05 & 0.06 & 0.05 & 25.70 & $\mathrm{~ns}$ & $\mathrm{~ns}$ \\
$\mathrm{Ed}(0.02 / \mathrm{h})$ & 57.24 & 58.09 & 58.62 & 58.76 & 58.18 & 1.37 & $\mathrm{~ns}$ & $\mathrm{~ns}$ \\
$\mathrm{Ed}(0.05 / \mathrm{h})$ & 52.12 & 53.01 & 53.61 & 53.76 & 53.12 & 1.57 & $\mathrm{~ns}$ & $\mathrm{~ns}$ \\
$\mathrm{Pd}$ & 65.60 & 66.38 & 65.92 & 65.31 & 65.80 & 3.30 & $\mathrm{~ns}$ & $\mathrm{~ns}$ \\
\hline
\end{tabular}

Dry matter degradability of corn silage (\%)

\begin{tabular}{lcccccccc} 
A & 20.92 & 21.22 & 20.05 & 22.34 & 21.13 & 10.19 & ns & ns \\
B & 47.50 & 47.92 & 48.66 & 52.73 & 49.20 & 7.46 & ns & ns \\
C $(\% / h)$ & 0.09 & 0.08 & 0.12 & 0.07 & 0.09 & 33.87 & ns & ns \\
Ed $(0.02 / h)$ & 58.72 & 58.79 & 60.88 & 58.82 & 59.30 & 3.47 & ns & ns \\
Ed $(0.05 / h)$ & 50.09 & 49.92 & 53.33 & 49.44 & 50.70 & 5.12 & ns & ns \\
Pd & 68.42 & 69.14 & 68.72 & 75.07 & 70.33 & 7.85 & ns & ns \\
\hline
\end{tabular}

$\mathrm{CV}=$ coefficient of variation; $\mathrm{ns}=$ non-significant; $*=\mathrm{P}<0.05 ; \mathrm{L}=$ linear effect; $\mathrm{Q}=$ quadratic effect.

There was no difference $(P>0.05)$ in $\mathrm{Pd}$, fractions $\mathrm{A}$ and $\mathrm{B}$, and degradation rate $\mathrm{C}$ with $2.00 \% / \mathrm{h}$ passage rate of concentrate dry matter in the levels of corn silage replacement by sugarcane. Effective degradability on $5.00 \% / \mathrm{h}$ passage rate had a quadratic effect with maximum degradation at $51 \%$ of sugarcane inclusion in the diet. Potential degradability of concentrate dry matter was 93.28 , indicating that the maximum degradation can be attributed to nonstructural carbohydrates, true protein, and protein nitrogen of the concentrate.

The percentages of sugarcane and corn silage reduction were 66.79 and $72.62 \%$, respectively, at $96 \mathrm{~h}$ of incubation and the concentrate was $93.06 \%$ at $48 \mathrm{~h}$ of incubation (Figure 3). The value observed in sugarcane was higher than those found by Pinto et al. (2007) of 55.00 and $62.00 \%$ with sugarcane treated with 0 and $6.00 \%$ of sodium hydroxide, respectively, at $144 \mathrm{~h}$ of incubation. Carmo et al. (2001) observed a value of $53.80 \%$ at $96 \mathrm{~h}$ of incubation with 
different protein sources in cattle

feeding.

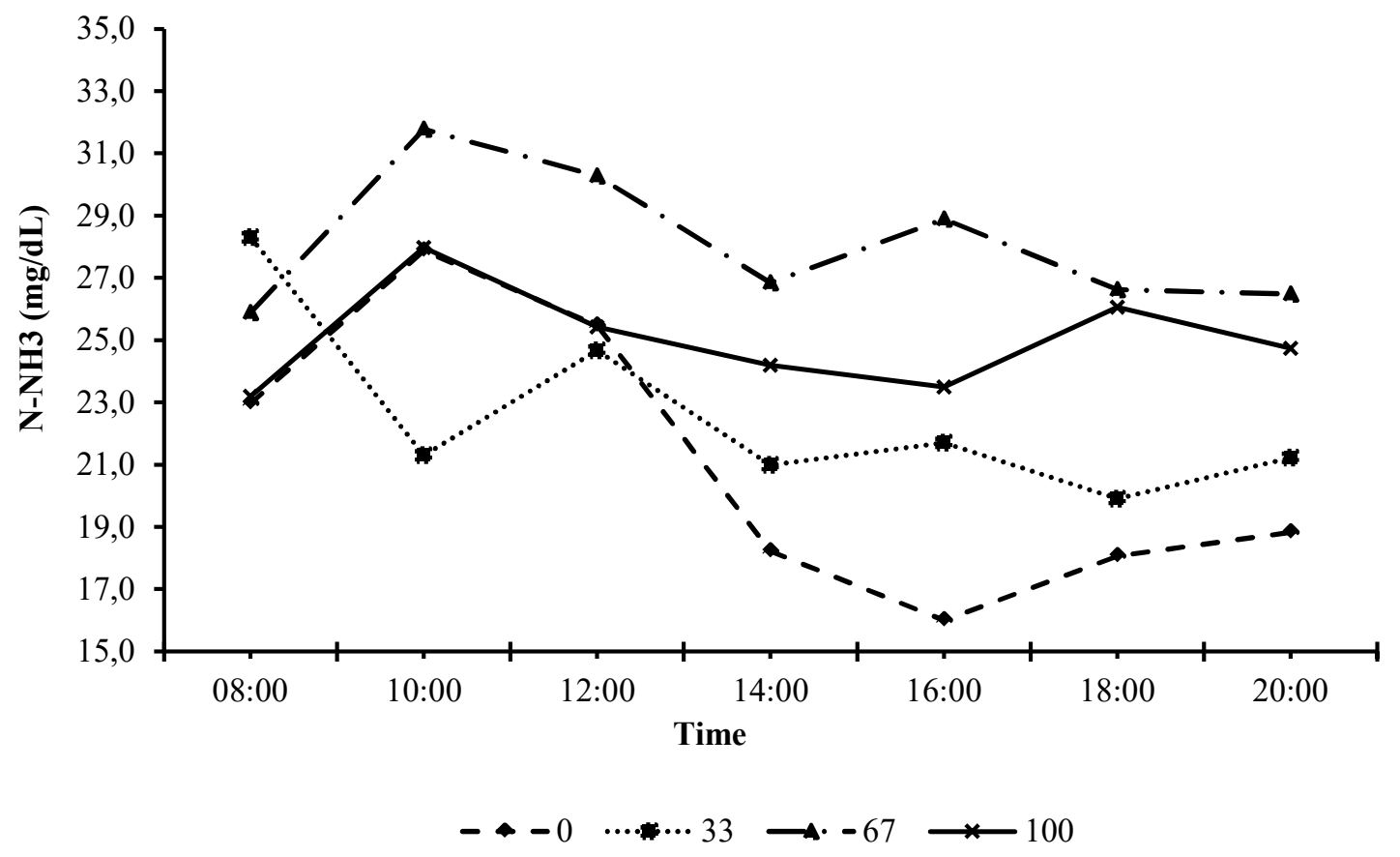

Figure 3. Effect of the levels of substitution of corn silage by sugarcane on ammonia nitrogen as a function of time

Potential degradability, fraction B degradability, and degradation rate $\mathrm{C}$ of sugarcane and corn silage NDF were not influenced $(P>0.05)$ by the different rumen environments of goats fed crescent levels of sugarcane in replacement of corn silage (Table 5). Potential degradability of sugarcane was higher than those found by Santos et al (2008) of 20.88 and $34.00 \%$ in rumen environments of cattle fed fresh and ensiled sugarcane, respectively; and lower than what were verified by
Franzolin and Franzolin (2000), of 78.77 and $70.29 \%$ in buffalo and cattle, respectively. Possibly, the similarity of rumen environments did not damage NDF sugarcane degradability. No differences were observed $(P>0.05)$ in effective degradability with passage rates 2.00 and $5.00 \% / \mathrm{h}$ in NDF of studied forages in different rumen environments. Effective degradability $(0.02 / \mathrm{h})$ of sugarcane NDF had a mean of $23.92 \%$.

Table 5. Values of potentially soluble fraction (B) degradability, degradation rate (C), colonization time (L), and effective degradability (Ed) for passages rates of 2.00 and $5.00 \% / \mathrm{h}$ and potential degradability $(\mathrm{Pd})$ of NDF of forages, as well as $\mathrm{CP}$ of concentrate as a function of sugarcane levels in replacement of corn silage

\begin{tabular}{cccccccc}
\hline \multirow{2}{*}{ Variable } & \multicolumn{3}{c}{ Replacement levels (\%) } & Mean & CV (\%) & Regression \\
\cline { 2 - 7 } & 0 & 33 & 67 & 100 & L & Q \\
\hline \multicolumn{6}{c}{ NDF sugarcane degradability (\%) } \\
\hline
\end{tabular}




\begin{tabular}{|c|c|c|c|c|c|c|c|c|}
\hline B & 38.71 & 40.90 & 37.96 & 36.79 & 38.59 & 14.21 & ns & ns \\
\hline $\mathrm{C}(\% / \mathrm{h})$ & 0.04 & 0.03 & 0.04 & 0.04 & 0.04 & 32.87 & ns & ns \\
\hline $\mathrm{L}$ & 5.28 & 4.97 & 5.24 & 5.53 & 5.25 & 28.84 & $\mathrm{~ns}$ & ns \\
\hline $\operatorname{Ed}(0.02 / \mathrm{h})$ & 23.56 & 23.97 & 24.18 & $23 ., 95$ & 23.92 & 4.31 & ns & ns \\
\hline $\operatorname{Ed}(0.05 / \mathrm{h})$ & 15.28 & 15.24 & 16.25 & 15.98 & 15.69 & 7.59 & $\mathrm{~ns}$ & $\mathrm{~ns}$ \\
\hline \multirow[t]{2}{*}{$\mathrm{Pd}$} & 38.71 & 40.90 & 37.96 & 36.79 & 38.59 & 14.21 & ns & ns \\
\hline & \multicolumn{8}{|c|}{ NDF corn silage degradability (\%) } \\
\hline B & 59.14 & 51.67 & 48.98 & 50.00 & 52.45 & 10.49 & ns & ns \\
\hline $\mathrm{C}(\% / \mathrm{h})$ & 0.03 & 0.04 & 0.06 & 0.05 & 0.05 & 28.55 & ns & ns \\
\hline $\mathrm{L}$ & 7.05 & 4.96 & 3.53 & 4.57 & 5.03 & 21.54 & ns & $*$ \\
\hline $\operatorname{Ed}(0.02 / h)$ & 32.62 & 33.66 & 35.14 & 34.72 & 34.03 & 5.08 & ns & ns \\
\hline $\operatorname{Ed}(0.05 / h)$ & 20.07 & 22.43 & 24.99 & 23.96 & 22.86 & 10.11 & ns & ns \\
\hline $\mathrm{Pd}$ & 59.14 & 51.67 & 48.98 & 50.00 & 52.45 & 10.49 & ns & $\mathrm{ns}$ \\
\hline
\end{tabular}

A quadratic effect was observed for colonization time (L) in NDF corn silage degradability with minimum value at $68.8 \%$ sugarcane inclusion in the diet. The mix of forages in this proportion could have reduced the selection by the animals, favoring the colonization of microorganisms and reducing colonization time in NDF corn silage degradability. According to Ryle and Ørskov (1987), forage diets demand longer mastication and rumination time, promoting abundant salivation, resulting in stable ruminal $\mathrm{pH}$ and favoring the survival of protozoa.

The percentages of NDF reduction were 37.10 and 51.82 for sugarcane and corn silage, respectively, at $96 \mathrm{~h}$ of incubation (Figure 4), and this result for sugarcane degradability was similar to that described by Carmo et al. (2001) of $35.96 \%$, and Pinto et al. (2007) of $48.00 \%$, at 96 and $144 \mathrm{~h}$ of incubation, respectively. 


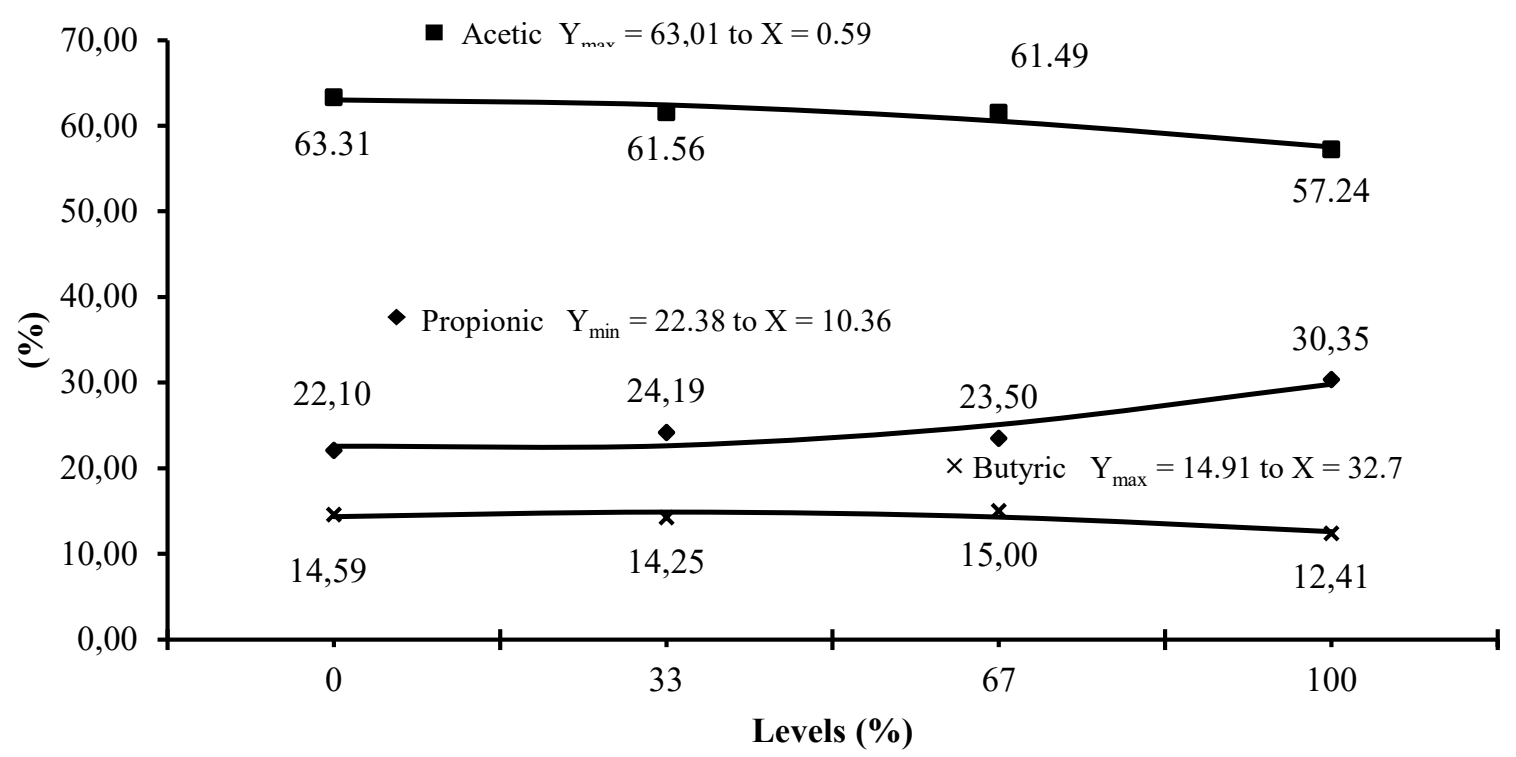

Figure 4. Concentration of short-chain fatty acids as a function of the levels of substitution of corn silage by sugarcane

\section{CONCLUSIONS}

Sugarcane can replace corn silage in a forage: concentrate ratio of 40:60 and used in maintenance adult goats without affecting dry matter intake.

Sugarcane as a replacement for corn silage favored propionate production.

In general, the rumen environments of animals fed different levels of sugarcane in replacement of corn silage showed similar values of sugarcane and corn silage degradation.

\section{ACKNOWLEDGEMENTS}

We thank the Foundation of São Paulo State Research (FAPESP) for supporting this research.

\section{REFERENCES}

AOAC (Association of official Analytical Chemist), 1977. Official methods of analysis, $16^{\text {th }}$ ed. Association of Official Analytical Chemist, Gaithersburg.

Aroeira, L.J.M., Lopes, F.C.F., Dayrell, M.S., Lizieire, R.S., Torres, M.P., 1995.

Digestibilidade, degradabilidade e taxa de passagem da cana-de-açúcar mais ureia e do farelo de algodão em vacas mestiças Holandês x Zebu em lactação.

Revista Brasileira de Zootecnia, Viçosa, 24, (6), 1016-1026.

Bergman, E.N., 1990. Energy contribution of volatile fatty acids from the gastrointestinal tract in various species. Physiological Reviews, 70, (2), 567-590.

Carmo, C.A., Berchielli, T.T., Andrade, P., Zeola, N.M.B.L., 2001. Degradabilidade da matéria seca e fibra em detergente neutro da cana-de-açúcar (Saccharumspp) com diferentes fonte de 
proteína. Revista Brasileira de Zootecnia, 30, (6), 2126-2133.

Carvalho, F.A.N., Barbosa, F.A., McDowell, L.R., Nutrição de Bovinos a Pasto. 2. ed. Belo Horizonte: Papelform, 2003. 428p.

Church, D.C., 1993. The ruminant animal digestive physiology and nutrition, $2^{\text {nd }}$ ed. Waveland, New Jersey, p. 564.

Erwin, E.S., Marco, G.J., Emery, E.M., 1961. Volatile fatty acids analyses of blood and rumen fluid by gas chromatography. Journal Dairy Science, 44, 1768-1771.

Foldager, J., 1977. Protein requirement and non-protein nitrogen for high producing cow in early lactation. Thesis (Doctor of Animal Science), Michigan State University, East Lansing, MI.

Franzolin, R., Franzolin, M.H.T., 2000.

População protozoários ciliados e degradabilidade ruminal em búfalos e bovinos zebuínos. Revista Brasileira de Zootecnia, 9, (6), 1853-18612.

Gonçalves, A.L., Lana, R.D.P., Rodrigues, M.T., Vieira, R.A.M., De Queiroz, A.C., Henrique, D.S., 2001.

Degradabilidade ruminal da matéria seca e da fibra em detergente neutro de alguns volumosos utilizados na alimentação de cabras leiteiras, submetidas a dietas com diferentes relações volumoso: concentrado. Revista Brasileira de Zootecnia, 30, (6), 1893-1903.

Hoover, W.H., 1986. Chemical factors involved in ruminal fiber digestion.
Journal Dairy Science, 69, (10), 27552766.

Hoover, W.H., Stokes, S.R., 1991. Balancing carbohydrate and proteins for optimum rumen microbial yield. Journal Dairy Science, 74, (10), 36303643.

Kulasek, G.A., 1972. A micromethod for determination of urea in plasma, whole blood cells using urease and phenol reagent. Polish Archives Weter, 15, (4), 801-810.

Magalhães, A.L.R., Campos, J.M.S., Cabral, L.S., Mello, R., De Freitas, J.A., Torres, R.A., Valadares Filho, S.C., De Assis, A.J., 2006. Cana-de-açúcar em substituição à silagem de milho em dietas para vacas em lactação: Parâmetros digestivos e ruminais. Revista Brasileira de Zootecnia, 35, (2), 591-599.

McDonald, I., 1981. A revised model for estimation of protein degradability in the rumen. Journal Agriculture Science, 96, 237-239.

Mehrez, A.Z., Ørskov, E.R., 1977. A study of the artificial fiber bag technique for determining the digestibility of feeds in the rumen. Journal Agriculture Science, 88, (3), 645-665.

Mertens, D.R., 1996. Using fiber and carbohydrate analyses to formulate dairy rations, In: Informational conference with dairy and forage industries. Proceedings, Wisconsin: US Dairy Forage Research Center, 81-92.

NRC (National Research Council), 2001. Nutrient Requirements of Dairy 
Cattle, $6^{\text {th }}$ ed. National Academic Press, Washington, DC, p. 387.

Ørskov, E.R., 1986. Starch digestion and utilization in ruminants. Journal Animal Science, 63, (5), 1624-1633.

Ørskov, E.R., McDonald, I., 1979. The estimation of protein degradability in the rumen from incubation measurements weighted according to rate of passage. Journal Agricultural Science, 92, (1), 499-508.

Pinto, A.P., Mizobuti, I.Y., Ribeiro, E.L.D.A., 2007. Degradabilidade ruminal da cana-de-açúcar integral tratada com diferentes níveis de hidróxido de sódio. Ciências Agrárias, 28, (3), 503-512.

Ryle, M., Ørskov, E.R., 1987. Rumen ciliates and tropical feeds. World Animal Review, 64, 21-30.

Santos, F.A.P., 2006. Metabolismo de proteínas In: Berchielli, T.T., Pires, A.V., Oliveira, S.G.D. (Eds.) Nutrição de ruminantes, Funep, Jaboticabal, 255-286.

Santos, V.P.D., Bittar, C.M.M., Nussio, L.G., 2008. Degradabilidade in situ da matéria seca e da fração fibra da cana-deaçúcar fresca ou ensilada e da silagem de milho em diferentes ambientes ruminais. Acta Science Animal, 30, (2), 193-201.

SAS (Statistical Analysis Systems Institute Inc.), 2008. User's Guide: Version 9.2. SAS Institute Inc. Cary, NC, USA. (CD-ROM).

Strobel, H.J., Russell, J.B., 1986. Effects of $\mathrm{pH}$ and energy spilling on bacterial protein synthesis by carbohydrate- limited cultures of mixed rumen bacteria. Journal Dairy Science, 69, (11), 29412947.

Sutoh, M., Obara, Y., Miyamoto, S., 1996. The effect of sucrose supplementation on kinetics of nitrogen, ruminal propionate and plasma glucose in sheep. Journal Agronomic Science, 126, (1), 99-105.

Valadares Filho, S.D.C., Pina, D.D.S., 2006. Fermentação ruminal, In: Berchielli, T.T., Pires, A.V.; Oliveira, S.G. (Eds). Nutrição de ruminantes, Funep, Jaboticabal, 151-182.

Valvasori, E., Lavezzo, W., Lucci, C.D.S., 2001. Alterações na fermentação ruminal em bovinos fistulados alimentados com cana-de-açúcar como substituto da silagem de milho. Boletim Industria Animal, 58, (1), 35-45.

VanSoest, P.J., Robertson, J.B., Lewis, B.A., 1991. Symposium: carbohydrate methodology, metabolism, and nutritional implications in dairy cattle. Journal Dairy Science, 74, (10), 35833597.

Vanzant, E.S., Cochran, R.C., Titgemeyer, E.C., 1998. Standardization of in situ techniques for ruminant feedstuff evaluation. Journal Animal Science, 76, 2717-2729. 